\title{
Correction to: Dapagliflozin: A Review in Type 1 Diabetes
}

\author{
Julia Paik ${ }^{1} \cdot$ Hannah A. Blair ${ }^{1}$ \\ Published online: 26 November 2019 \\ (c) Springer Nature 2019
}

use, duplication, adaptation, distribution and reproduction in any medium or format, as long as you give appropriate credit original author(s) and the source, provide a link to the Creative Commons licence and indicate if changes were made.

The original article has been corrected.

Open Access This article is distributed under the terms of the Creative Commons Attribution-NonCommercial 4.0 International License (http://creativecommons.org/licenses/by-nc/4.0/), which permits any noncommercial use, distribution, and reproduction in any medium, provided you give appropriate credit to the original author(s) and the source, provide a link to the Creative Commons license, and indicate if changes were made.
The original article can be found online at https://doi.org/10.1007/ s40265-019-01213-x.

Julia Paik

demail@springer.com

1 Springer Nature, Private Bag 65901, Mairangi Bay, Auckland 0754, New Zealand 